Оболенцева Л. В., д.е.н., доцент

Харківський наџіональний університет міського господарства імені О. М. Бекетова м. Харків, Украӥна

DOI: https://doi.org/10.30525/978-9934-26-036-0-18

\title{
ВИЯВЛЕННЯ ОСНОВНИХ ПРОБЛЕМ РОЗВИТКУ ТУРИСТИЧНОГО ІМІДЖУ МІСТА
}

Імідж території $є$ окремим випадком поняття «імідж» і являє собою іï образ, який склався у широкого кола осіб: жителів території, туристів, що відвідали цю територію та інших осіб, які мають про цю територію певне уявлення.

Імідж міста залежить від багатьох факторів, які можна поділити на дві групи: об'єктивні і суб'єктивні [1]. До об'єктивних факторів відносяться: географічне положення; історія та культура; соціальна політика; науково-технічний потенціал; інноваційна політика; інвестиційний клімат; статистичні показники та рейтинги території. Суб'єктивні фактори складаються з: сприйняття споживачами рівня гостинності на основі менталітету 
і національних особливостей; сприйняття споживачами атрибутивних знаків території; імідж територіального лідера в очах громадськості; вплив комунікаційної політики на сприйняття іміджу.

Імідж може бути як позитивним, так і негативним. Звичайно, керівництво будь-якого міста прагне створити якщо не унікальний, то сприятливий імідж. Оскільки імідж - це поняття багатогранне, тому злиття різних аспектів, таких як культура, рівень життя, освіти, розвиненість інфраструктури, туризму в цілому, економічний розвиток формують так званий імідж міста. Формування власного іміджу і посилення моментів впізнаваності окремого міста сприяє залученню до нього уваги, дає можливість більш ефективно лобіювати свої інтереси, покращувати інвестиційний клімат, отримувати додаткові ресурси для розвитку регіональної економіки.

Вплив позитивного іміджу туристичної території можна представити у якості:

I. Соціально-економічного ефекту: розвиток туристичної інфраструктури і сфери обслуговування; розширення переліку надаваних послуг; розвиток нових видів діяльності; підвищення рівня життя населення; створення додаткових робочих місць для місцевого населення.

II. Соціокультурного ефекту: збереження культурної спадщини; розвиток народних художніх промислів; сприяння створенню та підтримки музеїв, збереження i фінансування культурно-історичних пам'яток; посилення почуття гордості місцевого населення за свою культуру; забезпечення можливостей для міжкультурних обмінів.

Задля отримання як соціально-економічного, так соціокультурного ефектів від позитивного впливу туристичного іміджу міста Харків необхідно виявити основні тенденції та основні проблеми розвитку туристичного іміджу міста.

План розвитку туризму повинен стати найважливішою складовою програми соціально-економічного розвитку Харкова. 
Розвиток рекреації і туризму повинен привести до формування здорового способу життя населення i забезпечити істотний внесок в економіку регіону не тільки від безпосередніх доходів, але і забезпечуючи вплив на сектори економіки, які характеризуються непрямим впливом.

Харків має достатній природний, культурний та історичний потенціал, здатний стати основою для створення умов для формування в місті конкурентоспроможної туристичної галузі, як однієї зі сфер економіки, що забезпечує стабільний внесок в соціально-економічний розвиток міста за рахунок зростання інвестицій, поповнення дохідної частини місцевого бюджету, збільшення кількості робочих місць, поліпшення добробуту населення, збереження та раціонального використання культурноісторичної та природної спадщини, створення іміджу на території, сприятливої для туризму, відпочинку та оздоровлення.

Основними, першочерговими проблемами розвитку туризму в місті є: 1) створення і розвиток сучасної інфраструктури - це найбільш кардинальна, складна і вимагає істотних капітальних вкладень проблема. Вона не може бути вирішена в короткі терміни. Необхідно домогтися включення об'єктів туристичної інфраструктури в довгострокові регіональні програми розвитку туризму. Для цього буде потрібною розробка конкретних пропозицій, проектів з попередньою оцінкою вартості будівництва або реконструкції, а також подальшої прибутковості; 2) неефективне використання рекреаційних територій, придатних для створення туристично-рекреаційних об'єктів; 3) відсутність системи стимулювання інвестування в об'єкти туристичної індустрії; 4) недостатня кількість об'єктів відвідувань; 5) слабо розвинуті маркетингові дослідження, результати яких дозволяють прогнозувати розвиток туристичного ринку і вивчати власний туристичний потенціал; 6) відсутність механізмів використання та просування туристичних можливостей території; 7) дефіцит професійних туристичних кадрів; 8) недостатня кількість та асортимент послуг, які надаються в сфері оздоровлення, 
відпочинку, екскурсійного обслуговування, полювання, риболовлі та активних видів туризму.

Таким чином, стан розвитку туризму на території регіону при наявності значних потенційних можливостей ще не достатньо розвинений i потребує формування i забезпечення реалізації плану розвитку.

Очевидно, що вирішення зазначених проблем $є$ можливим лише завдяки формуванню програми чи плану розвитку, оскільки туризм - це сфера, в якій поєднана діяльність суб'єктів різних галузей економіки і соціальної сфери. Тому, в такій програмі має бути визначено взаємодію структурних підрозділів адміністрації, суб'єктів туристичної діяльності, музеїв, засобів розміщення туристів і інших. Розподіл функцій учасників представлено в табл. 1.

Таблиця 1

\section{Розподіл функцій учасників в забезпеченні і реалізації програми розвитку міста}

\begin{tabular}{|c|c|}
\hline Учасники & Функції дій учасників \\
\hline \multirow{3}{*}{ Адміністрація регіону } & $\begin{array}{c}\text { забезпечує проведення організаційно-правової } \\
\text { та методичної роботи з реалізації Програми }\end{array}$ \\
\hline & $\begin{array}{c}\text { виділяє цільові кошти на реалізацію заходів } \\
\text { Програми, спрямованих на просування } \\
\text { турпродукту регіону та поліпшення } \\
\text { інфраструктури муніципальних об’єктів показу }\end{array}$ \\
\hline & $\begin{array}{c}\text { залучає позабюджетні кошти і направляє їх на } \\
\text { реалізацію програмних заходів, на формування } \\
\text { сприятливого туристичного іміджу міста }\end{array}$ \\
\hline \multirow{2}{*}{$\begin{array}{l}\text { Структурні підрозділи } \\
\text { адміністрації регіону } \\
\text { та туристичні } \\
\text { організації }\end{array}$} & беруть участь у реалізації заходів \\
\hline & $\begin{array}{c}\text { виділяють власні кошти для організації просування } \\
\text { турпродукту регіону на туристичному ринку }\end{array}$ \\
\hline
\end{tabular}

Таким чином, реалізація програми розвитку дозволить об'єднати зусилля різних суб'єктів туристичної діяльності щодо вдосконалення використовуваного турпродукту. Реалізація комплексу заходів дозволить: 1) збільшити кількість об'єктів 
розміщення туристів (готелі, мотелі, бази відпочинку, і так далі); 2) підвищити якість обслуговування туристів і екскурсантів; 3) поліпшити взаємодію органів місцевого самоврядування регіону та поселень 3 організаціями туристичної сфери; 4) сформувати привабливий імідж Харкова.

Тобто, якщо усунути, виявлені в ході аналізу існуючої ситуації основні причини, які перешкоджають розвитку туристичної індустрії на території Харківського регіону, а саме: недостатній рівень розвитку і недосконалість туристичної інфраструктури; відсутність позитивного туристичного іміджу Харкова та області; відсутність туристичного продукту, що сприяє впізнаваності міста; поганий стан об'єктів культурної спадщини, - то можна досягти зазначеної мети та поставлених задач, адже для цього у Харкова є всі об'єктивні передумови.

Підсумовуючи проведене дослідження необхідно зазначити, що імідж повинен бути визнаний в якості одного з важливих активів території, оскільки в його основі лежать єдині в своєму роді особливості території, які необхідно вивчати, розвивати i активно просувати.

Концепція формування іміджу немислима без участі всіх найбільш значущих для цього процесу держаних структур.

Просування іміджу території - перспективний шлях подолання труднощів у формуванні іміджу Харкова в цілому. За останні роки технології формування іміджу туристичної території знаходять все більше застосування в сфері туризму, оскільки створення сприятливого іміджу туристичної території відноситься до ключових напрямів діяльності щодо просування туристичних послуг з метою формування конкурентних переваг та підвищення свого конкурентного статусу.

\section{Література:}

1. Калиева О. М. Факторы, влияющие на формирование имиджа города. Молодой ученый. 2014. № 2. С. 439-441. 